\title{
Article \\ The Production of Carbon Nanofiber on Rubber Fruit Shell-Derived Activated Carbon by Chemical Activation and Hydrothermal Process with Low Temperature
}

\author{
Suhdi Suhdi (1) and Sheng-Chang Wang * \\ Department of Mechanical Engineering, Southern Taiwan University of Science and Technology, \\ Tainan City 71005, Taiwan; da61y203@stust.edu.tw \\ * Correspondence: scwang@stust.edu.tw; Tel.: +886-6-253313 (ext. 3501)
}

Citation: Suhdi, S.; Wang, S.-C. The Production of Carbon Nanofiber on Rubber Fruit Shell-Derived Activated Carbon by Chemical Activation and Hydrothermal Process with Low Temperature. Nanomaterials 2021, 11, 2038. https://doi.org/10.3390/ nano11082038

Academic Editor: Takuya Kitaoka

Received: 29 June 2021

Accepted: 9 August 2021

Published: 10 August 2021

Publisher's Note: MDPI stays neutral with regard to jurisdictional claims in published maps and institutional affiliations.

Copyright: (c) 2021 by the authors. Licensee MDPI, Basel, Switzerland. This article is an open access article distributed under the terms and conditions of the Creative Commons Attribution (CC BY) license (https:/ / creativecommons.org/licenses/by/ $4.0 /)$.

\begin{abstract}
Recently, the conversion of biomass into carbon nanofibers has been extensively studied. In this study, carbon nanofibers (CNFs) were prepared from rubber fruit shell (RFS) by chemical activation with $\mathrm{H}_{3} \mathrm{PO}_{4}$, followed by a simple hydrothermal process at low temperature and without a vacuum and gas catalyst. XRD and Raman studies show that the structure formed is an amorphous graphite formation. From the thermal analysis, it is shown that CNFs have a high thermal stability. Furthermore, an SEM/TEM analysis showed that CNFs' morphology varied in size and thickness. The obtained results reveal that by converting RFS into an amorphous carbon through chemical activation and hydrothermal processes, RFS is considered a potential biomass source material to produce carbon nanofibers.
\end{abstract}

Keywords: rubber fruit shell; nanofibers; hydrothermal

\section{Introduction}

As is known, carbon nanofibers (CNFs) are an essential material of carbon. That has been widely studied in various basic scientific research and industrial applications. CNFs are one of the most important members of carbon fibers that are usually useful in many applications due to their unique mechanical, physical, chemical, and electrical [1,2] properties, and they also have fibrous, cylindrical, and cup-stacked structures that can produce a nano-scaled quantum effect [3]. CNFs are carbon allotropes with a diameter of around 50-100 $\mathrm{nm}$ and a length of between one and a hundred micrometers [4].

The utilization of carbon nanofibers (CNFs) as a potential material has recently been demonstrated in a variety of fields, such as adsorbents [5,6], sensors [2,7], electrode materials and electromagnetic shielding [8], batteries, solar cells [9], supercapacitors [3], gas storage [10,11], and biomedical applications [12-14]. Due to the rising usage of CNFs in various applications, the demand for CNF has risen in recent years, accompanied by an increase in selling prices. As a result, alternate approaches to producing low-cost CNFs must be identified. In most cases, these initiatives aim to lower costs by using less expensive materials, lowering costs through processing or combining the two approaches.

Numerous kinds of CNF have been produced recently from a variety of sources. Nevertheless, the majority of CNFs are derived from non-renewable precursors [15]. Due to their limitations and unsustainable characteristics as significant concerns, the organic polymer sources from biomass have been heavily studied in recent years, such as bamboo [16], mango seed and bleached Kraft pulp [6], sawdust [17], crab shell [18], and natural fungus [19]. Biomass is a lignocellulosic plant material composed of different polymers, including cellulose (40-50\%), hemicellulose (20-40\%), and lignin (10-15\%) [20]. Lignin is a natural polymer that is the most effective replacement for producing carbon nanofibers, particularly with the addition of phosphoric acid $\left(\mathrm{H}_{3} \mathrm{PO}_{4}\right)$ to the lignin solution, more curled fibers will form [5] and cellulose as cellulose nanofibers [21,22]. Exploring different 
resources is substantial considering that the characteristics of cellulosic material can be changed by plant age and location, seasonal climate conditions, and impurity extraction processes [23]. As a result, finding a bio-based precursor material for CNF synthesis is essential.

Rubber fruit is a potentially renewable resource for the production of CNF precursors since the shell of the rubber fruit (Hevea brasiliensis) is reported to contain between $35 \%$ and 54\% lignin [6]. However, relatively few investigations/reports have been published on rubber fruit shells, considered potential precursors for carbon fiber synthesis. According to recent research, several studies have used rubber fruit as a raw material for various purposes. Some studies demonstrate the use of seeds as food, feed, and biofuel [24,25]. Several studies have utilized rubber seed shell (RSS) to produce high-quality activated carbon via physical activation with steam [26], a promising precursor of activated carbon for phenol removal from water [27], activated carbon as a potential CO2 removal, where the activation process is performed with malic acid [28,29] and the use of RSS as a filler in polymer technology [30]. While several studies employ rubber fruit shell (RFS) as a raw material, they include the production of activated carbon as a bio sorbent for removing free fatty acid (FFA) from crude palm oil (CPO) [6], producing activated carbon for wastewater treatment [31] and producing activated carbon as a pack carburizing medium in the heat treatment process [32]. From the information above, it is clear that RSS and RFS have only been used as precursors in the manufacture of activated carbon, but not yet in the manufacture of CNFs.

Indonesia is the second-largest producer of rubber in the world [33]. According to statistical data, Indonesia has the world's largest rubber plantation area, at approximately $3,671,387$ ha in 2020, with production reaching 3.54 million tons of rubber [34]. Rubber plantations have historically focused exclusively on latex and stem processing, with little attention paid to other products such as rubber fruit. Rubber fruit is a by-product of Indonesia's extensive rubber plantations. Rubber fruit has historically had little economic value and has been used exclusively as a generative seed for rubber trees. The rubber fruit comprises three major components: the fruit shell, the seed shell, and the seed itself, with the fruit shell accounting for $70 \%$ of the total weight, $9 \%$ of the seed shell, and $21 \%$ of the seed [35]. Rubber plantations produce approximately $1000 \mathrm{~kg}$ of rubber fruit per hectare per year [4], equating to approximately 3.6 million tons of rubber fruit per year. Therefore, raw materials will be available in the form of rubber fruit shells (RFS) of 2.569 million tons per year, rubber seed shells (RSS) of 0.330 million tons per year, and rubber seeds (RS) of 0.771 million tons per year. This number is the large quantity of raw material as a greener precursor material derived from renewable plant-based resources, particularly for RFS, which is desirable for CNFs precursor synthesis.

Carbon nanofibers synthesized from biomass can be produced in various methods. The first is the electrospinning method $[3,8,36]$, which consists of an electrospinning process followed by a heat treatment procedure, and it can produce multifunctional carbon materials such as carbon nanofibers (CNFs) with diameters ranging from a few tens of nanometers to several micrometers [21,22]. The biomass material is chemically treated to yield biomass fibers, which are then mixed with a polymer solution, placed in a capillary tube, and carbonized at temperature $>600^{\circ} \mathrm{C}[3,22,37]$. The second method is pyrolysis [23] which can also be used to produce crosslinked carbon nanofibers. During pyrolysis, the biomass formed by complex organic structures undergoes a series of decomposition steps, starting with the release of water vapor followed by the decomposition of hemicellulose, cellulose, and lignin. However, pyrolysis involves high electricity consumption because it needs to be carried out at high temperatures of up to $900{ }^{\circ} \mathrm{C}$. The third method is ultrasonication [38] which degrades the material by using ultrasonic waves at a frequency higher than $20 \mathrm{kHz}$ combined with a liquid medium such as a solvent or polymer melt [5]. The last and most frequently utilized method is hydrothermal synthesis [39-41]. The production of nanomaterials in hydrothermal synthesis may occur across a broad temperature range, from a low to extremely high temperature, and in either a low or high-pressure 
environment depending on the main composition [40]. Recently, many researchers have used hydrothermal synthesis at low temperatures because of its energy-saving property and simple synthesis. Manafi et al. [42] used an easy sonochemical/hydrothermal method at $160^{\circ} \mathrm{C}$. Funke et al. [43] used elevated temperatures $\left(180-220^{\circ} \mathrm{C}\right)$ for biomass in a water suspension under saturated pressure for a few hours. Deng et al. [19] extracted nanofibers from biomass carbon, Teflon-coated stainless steel autoclave was added, and $70 \mathrm{~mL}$ of $3 \mathrm{M}$ $\mathrm{KOH}$ solution was added and treated at $150{ }^{\circ} \mathrm{C}$. However, almost all of these methods are synthesized using catalysts such as $\mathrm{Ni}, \mathrm{Co}$, and $\mathrm{Fe}$, and require gases and vacuum support to obtain nanostructured materials $[23,44,45]$.

As mentioned above, several studies have demonstrated that precious CNFs may be produced from biomass feedstocks. However, the majority of these procedures require high reaction temperatures and metal catalysts. As a result, we used a more environmentally friendly precursor material obtained from a renewable plant resource (rubber fruit shell) to synthesize carbon nanofibers in the present study. The RFS as a precursor was carbonized via pyrolysis and then chemically activated with phosphoric acid $\left(\mathrm{H}_{3} \mathrm{PO}_{4}\right)$, and then to obtain CNFs, the rubber fruit shell activated carbon (RFSAC) was carried out by a simple hydrothermal process without the addition of catalysts, at low temperature $\left(90^{\circ} \mathrm{C}\right)$, and vacuum and gasses were not required.

\section{Materials and Methods}

\subsection{Material Preparation}

In this study, the precursor was prepared from rubber fruit shells collected from Bangka Island of Indonesia through washing, drying, carbonization, pulverization, and dan sieving processes according to a previous study by the authors [32]. The RFS was first submerged in $10 \% \mathrm{H}_{2} \mathrm{SO}_{4}$ for $4 \mathrm{~h}$, rinsed in distilled water to remove soil contaminants, and dried at $60^{\circ} \mathrm{C}$ for $24 \mathrm{~h}$. The dried precursor was carbonized for $1 \mathrm{~h}$ at $450{ }^{\circ} \mathrm{C}$ in nitrogen $(20 \mathrm{~mL} / \mathrm{min})$. Finally, The RFS were then crushed and sieved at 200 mesh $(74 \mu \mathrm{m})$ sieve size as shown in Figure 1.

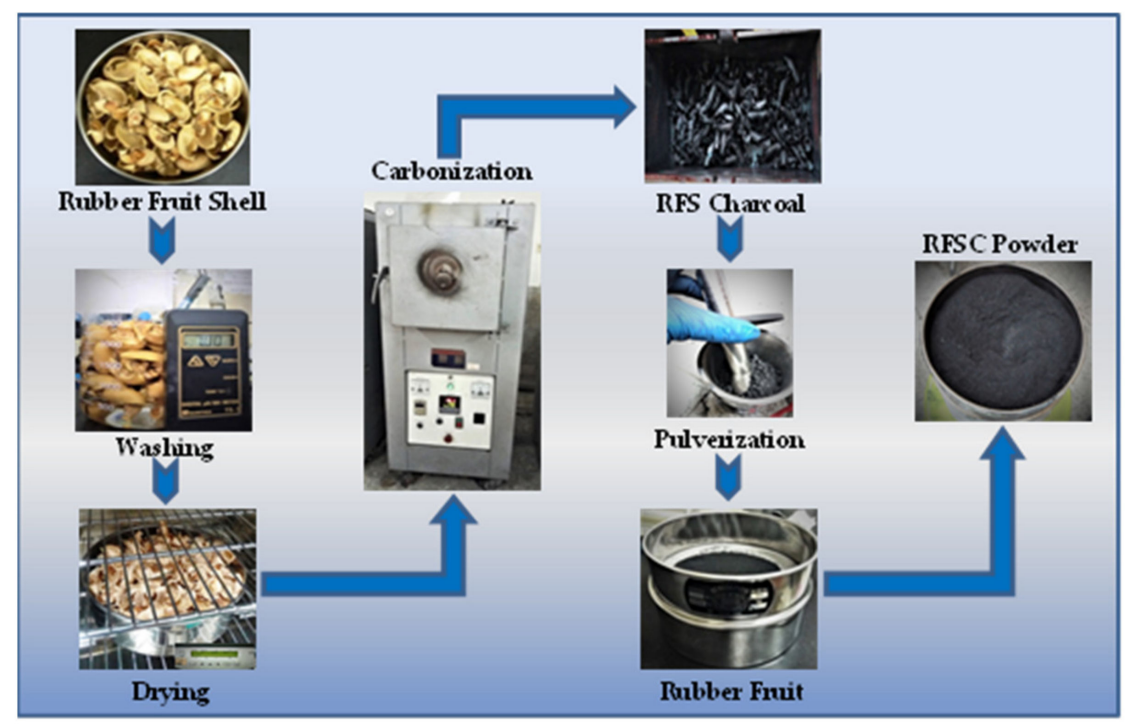

Figure 1. The rubber fruit shell charcoal (RFSC) powder manufacturing process flow.

The $3 \mathrm{~g}$ powder of rubber fruit shell charcoal (RFSC) was impregnated with phosphoric acid $\left(\mathrm{H}_{3} \mathrm{PO}_{4}\right) 85 \%$ by weight solution in water supplied by Fisher Scientific $[46,47]$. The impregnation ratio between charcoal weight and the activating agent was 1:4 wt ratio. The slurry was mixed for $1.5 \mathrm{~h}$ at $300 \mathrm{rpm}$ with a magnetic stirrer (Corning PC-420D, Corning Inc., Corning, NY, USA). The homogeneous slurry was dried in the oven (VENTICELL 55, MMM Medcenter Einrichtungen $\mathrm{GmbH}$, Munich, Germany) at $110^{\circ} \mathrm{C}$ overnight. Then, 
the black and sticky slurries were put in a ceramic crucible and carbonized in the furnace (Muffle furnace KL 03/11, THERMCONCEPT GmbH, Bremen, Germany) at $500{ }^{\circ} \mathrm{C}$ at a rate of $10^{\circ} \mathrm{C} / \mathrm{min}[46,47]$. The activation time was in range of $60 \mathrm{~min}$, in a self-generated atmosphere and cooled to room temperature. The samples of rubber fruit shell activated carbon (RFSAC) were washed using distilled water mixed with $\mathrm{NaOH}$ solution and centrifuged for $30 \mathrm{~min}$ at $1000 \mathrm{rpm}$ repeatedly to remove the excess activating until a pH of around seven was achieved. After this process was complete, the hydrothermal process was performed. The supernatant was immersed in $40 \mathrm{~mL}$ distilled water and stirred at $60{ }^{\circ} \mathrm{C}, 300 \mathrm{rpm}$ for $3 \mathrm{~h}$, and was then placed in air for one day. In the last process, the solution was dried in the dry oven at $90^{\circ} \mathrm{C}$ for around three days until complete dryness. The processes as shown in Figure 2.

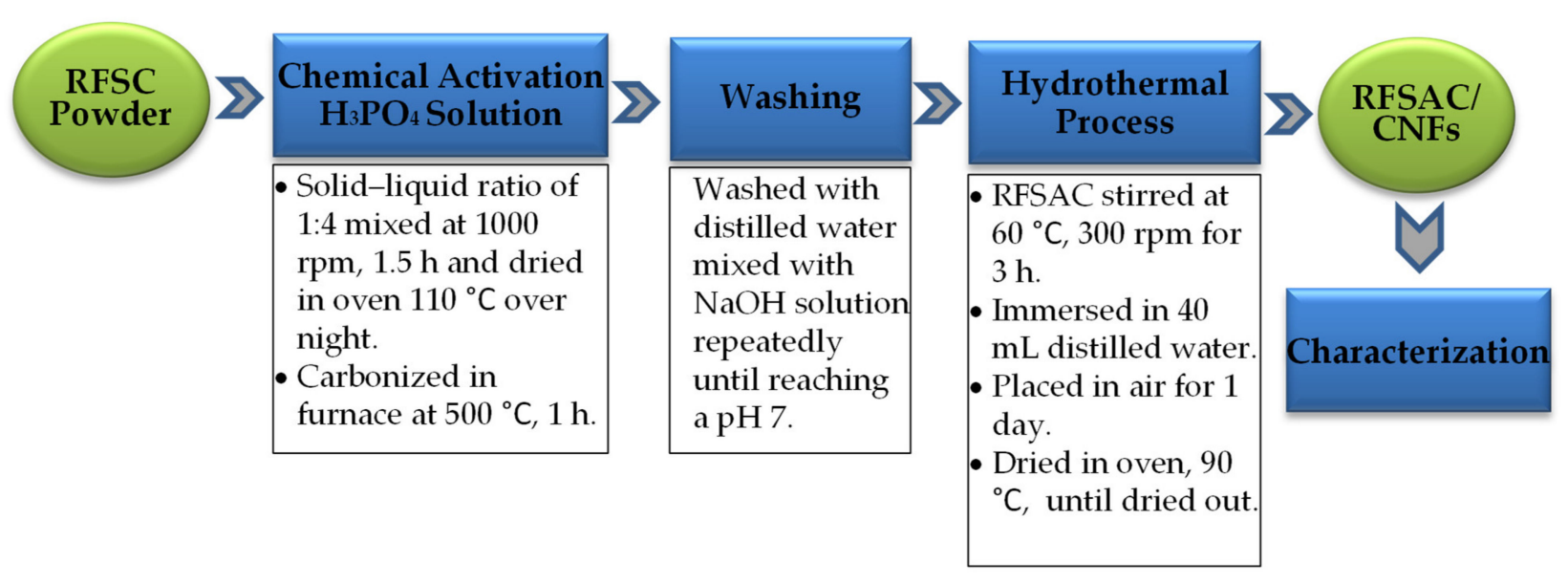

Figure 2. The chemical activation and hydrothermal processes.

\subsection{Characterization}

The thermal decomposition behavior of samples was analyzed by the Thermal Gravimetric Analysis (TGA) machine (METTLER TOLEDO-TGA/DSC1 STAR e System, Schweiz $\mathrm{GmbH}$, Greifensee, Switzerland) was used. The analysis was performed by heating the 9 to $10 \mathrm{mg}$ sample to $900{ }^{\circ} \mathrm{C}$ at a heating rate of $10^{\circ} \mathrm{C}$ in a nitrogen atmosphere and a $50 \mathrm{~mL} / \mathrm{min}$ flow rate. The curves of weight loss were re-plotted by Origin 8 software (OriginLab Corporation, Northampton, UK). The number of specific surface areas and pore volumes of sample products was determined by accelerated surface area and porosimetry system machine (ASAP 2020, Micromeritics Japan, G.K., Chiba, Japan). For this analysis, the sample's $0.2-0.3 \mathrm{~g}$ was used with an automated degas cycle, $\mathrm{N}_{2}$ adsorptive analysis, $-196^{\circ} \mathrm{C}$ bath temperature analysis, $10 \mathrm{~s}$ equilibration time, an ambient temperature at $22^{\circ} \mathrm{C}$. The specific surface areas were recorded using the Brunauer-Emmett-Teller (BET) technique and the assessment of pore volumes was obtained using the Barrett-JoynerHalenda (BJH) algorithm.

X-ray diffraction (Bruker, D2 Phaser, Karlsruhe, Germany) with $\mathrm{Cu} \mathrm{K} \alpha$ radiation from $10^{\circ}$ to $50^{\circ}$ was used to characterize the phase and crystal structure of as-synthesized electrocatalysts. Raman spectroscopy analysis was performed using Laser Spectroscopy Technologies Confocal Micro and Nano Raman (UniDRON, CL Technology Co., Ltd., New Taipei, Taiwan). To find out the morphological structure and the composition of sample elements, the instrument used was Scanning Electron Microscope-Energy Dispersive Spectroscopy (JEOL JSM-6701F, JEOL Ltd., Tokyo, Japan) and High-resolution Transmission Electron Microscopy (JEOL-JEM-1230, JEOL Ltd., Tokyo, Japan). The size and number of CNFs formed were determined, the SEM images were characterized using ImageJ software version 2.1.0/53k, Java 1.8.0_172(64 bit). The samples were processed 
using conventional methods, while the number of samples was around 273 grains. Then, plotted using histogram diagrams and Gaussian curves in Origin 8.

\section{Results}

\subsection{Thermogravimetric Analisys of RFSAC and Nanofibers}

Figure 3 shows the thermal decomposition behavior of the sample that was identified by thermogravimetric analysis (TGA). The curve shows that the weight loss of RFSAC started from $60{ }^{\circ} \mathrm{C}$ to $200{ }^{\circ} \mathrm{C}$, and the significant mass loss occurred due to water dehydration on the surface. The RFSAC began to decompose at about $200^{\circ} \mathrm{C}$, reducing mass to around $80 \%$ at $700{ }^{\circ} \mathrm{C}$; both the dehydrated water discharge and oxidation processes were responsible for the mass loss. The mass began to decrease steadily at higher temperatures (e.g., 700 to $900{ }^{\circ} \mathrm{C}$ ) due to the release of carbon dioxide [48]. In comparison, carbon nanofibers began to decompose at temperatures $300^{\circ} \mathrm{C}$ higher than RFSAC. At $900{ }^{\circ} \mathrm{C}$, the residue left weight percentage of carbon nanofibers was $26.7 \%$ higher than that of the RFSAC (15.7\%). The above results show that carbon nanofibers have a higher thermal stability.

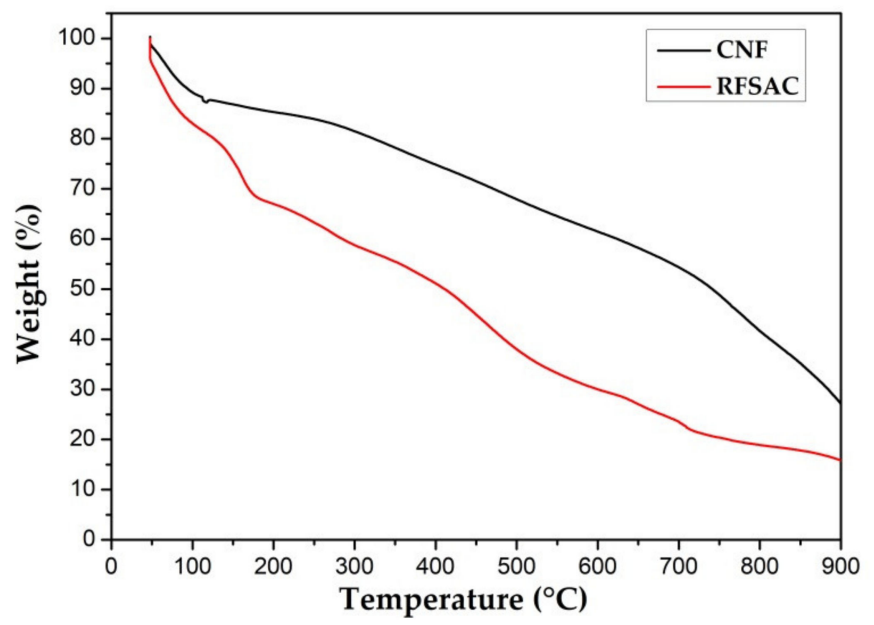

Figure 3. Thermal decomposition analysis result of RFSAC and carbon nanofibers.

\subsection{BET Specific Surface Area and Porosity of RFSAC and Carbon Nanofibers}

The specific surface area and total pore volume $\left(V t o t a l, \mathrm{~cm}^{2} / \mathrm{g}\right)$ were measured by the BET method in the isotherm region and calculated by $\mathrm{N}_{2}$ gas adsorption on the surface (see Figure 4). The specific surface area of CNFs was $63 \mathrm{~m}^{2} \mathrm{~g}^{-1}$ at $\mathrm{P} / \mathrm{P}_{0}=0.9902$, while $286 \mathrm{~m}^{2} \mathrm{~g}^{-1}$ for RFSAC at $\mathrm{P} / \mathrm{P}_{0}=0.9911$. The adsorption average pore size of CNFs $(2.11 \mathrm{~nm})$ was lower than the RFSAC $(2.76461 \mathrm{~nm})$. Whereas in this case, the average pore size influenced the specific surface area values because the CNFs primarily retained their pore structure, their surface area may be lower than that of RFSAC, which was exfoliated. The decrease in the specific surface area from 286 to $63 \mathrm{~m}^{2} \mathrm{~g}^{-1}$ was probably caused by the growth of CNFs that occurred on the surface or RFSAC pores, so that CNF not only moved to the RFSAC surface, but also lodged in the RFSAC pores. Several researchers observed similar findings, where they declared that CNFs/CNTs were found on the surface and within the pores of biomass-activated carbon-derived, such as; $\mathrm{Su}$ et al. [49] showed that following CNF formation, the specific surface area of palm shell-based AC was decreased from 1490 to $305 \mathrm{~m}^{2} \mathrm{~g}^{-1}$. Similarly, Chen et al. [45] found that the specific surface areas of wheat straw and coconut-derived AC decreased substantially following CNT development, from 1121 to $102 \mathrm{~m}^{2} \mathrm{~g}^{-1}$ and 1189 to $32 \mathrm{~m}^{2} \mathrm{~g}^{-1}$, respectively. 


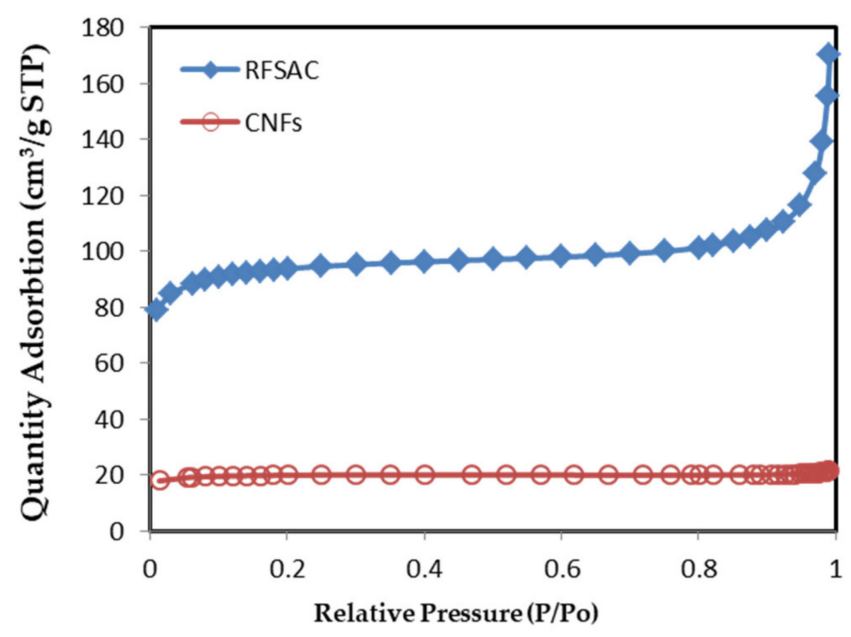

Figure 4. Nitrogen absorption isotherm RFSAC and carbon nanofibers.

\subsection{The Element Content of Carbon Nanofibers Grown on RFSAC}

The element content of CNFs grown on the RFSAC surface was identified by EDS (see Figure 5), and the results are shown in Table 1 . The three dominant elements produced were 62.48 at.\% carbon, 32.83 at.\% oxygen, and 4.38 at.\% phosphorus, while other elements such as silicon and potassium were less than 1 at.\%.

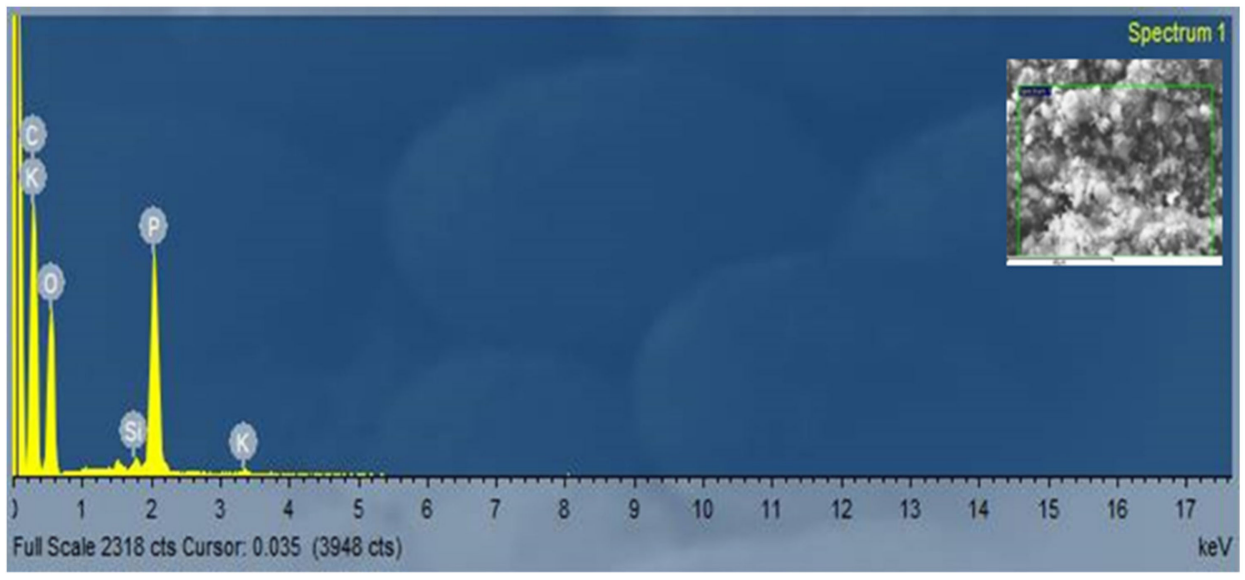

Figure 5. EDS spectrum of CNTs grown on the surface of RFSAC.

Table 1. Elemental content quantitative analysis.

\begin{tabular}{cccc}
\hline Element & Line & Intensity Corrn. & Atomic\% \\
\hline $\mathrm{C}$ & K_SERIES & 0.6678 & 62.48 \\
$\mathrm{O}$ & K_SERIES & 0.5744 & 32.83 \\
$\mathrm{Si}$ & K_SERIES & 0.9733 & 0.22 \\
$\mathrm{P}$ & K_SERIES & 1.3567 & 4.38 \\
$\mathrm{~K}$ & K_SERIES & 1.0071 & 0.09 \\
\hline Total & & & 100 \\
\hline
\end{tabular}

\subsection{Morphology and Microstructure of CNTs}

Figure $6 \mathrm{a}-\mathrm{c}$ SEM images show the clusters of CNFs formed on the activated carbon surfaces. According to SEM analysis, enmeshed CNFs with varied diameters plentifully surrounded the surface of the RFSAC. The structure and dimensions of CNFs were more clearly shown in TEM images in Figure $6 \mathrm{~d}-\mathrm{f}$, where the inhomogeneous dimensions of 
CNFs are visible. It was proven that this synthesis technique makes it possible to produce carbon nanofiber materials with varying diameters and lengths.

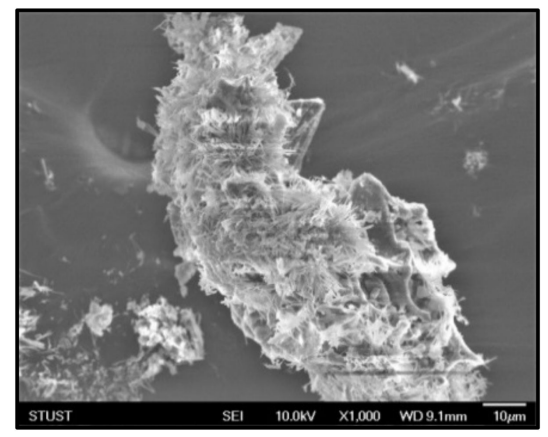

(a)

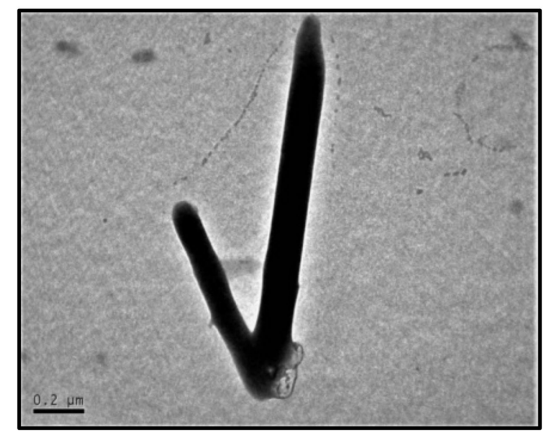

(d)

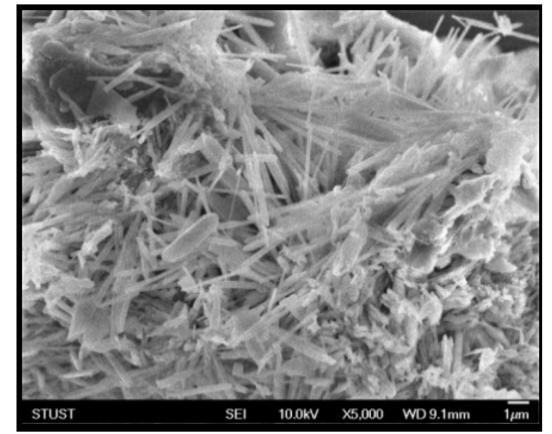

(b)

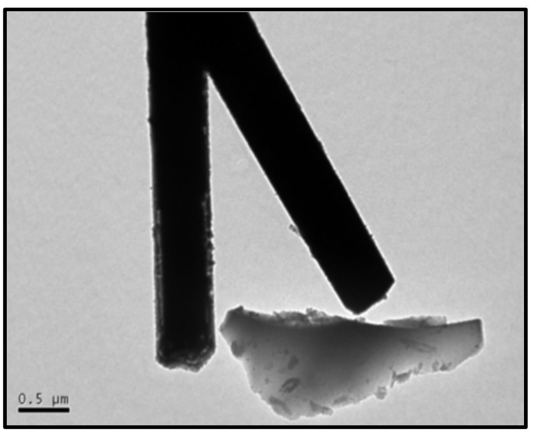

(e)

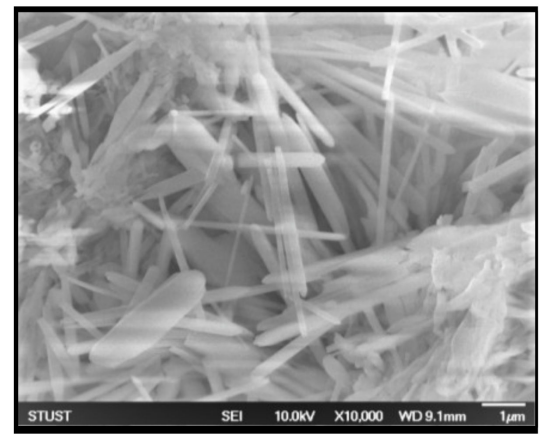

(c)

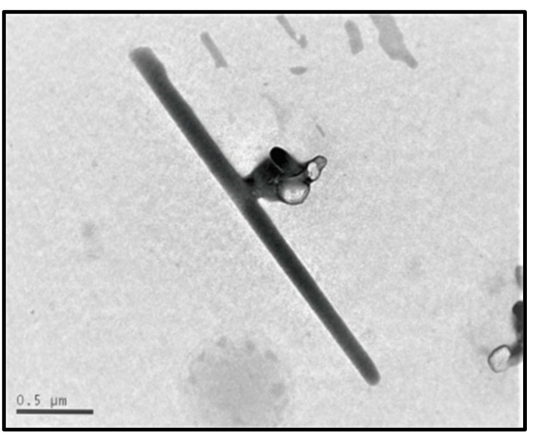

(f)

Figure 6. $(\mathbf{a}-\mathbf{c})$ SEM images and (d-f) TEM images of carbon nanofibers.

The microstructure of CNFs was investigated by XRD and the respective patterns are shown in Figure $7 \mathrm{a}$. In the result of XRD, there were two broad peaks $2 \theta$ at around $25.6^{\circ}$, and $43.0^{\circ}$ can be indexed to the (002) and (001) diffraction plane of CNFs with an amorphous or low crystallinity carbon phase, and those peaks were characteristic crystal planes of graphitic carbon [50]. The Raman spectrum of the CNF is shown in Figure 7b; there were two prominent peaks positioned at around 1340 and $1582 \mathrm{~cm}^{-1}$ which were labeled as D and G bands of carbon atom crystal, respectively. The D band was associated with defects and disorders in carbon materials, whereas the $\mathrm{G}$ band reflected the vibrational mode of two carbon atoms moving in opposite directions in a graphite [51]. The intensity ratio $\left(\mathrm{I}_{\mathrm{D}} / \mathrm{I}_{\mathrm{G}}\right)$ of the $\mathrm{D}$ and $\mathrm{G}$ bands represented the degree of the structural defect of the material and graphitization of the carbon nanofibers [50,51]. According to the Raman spectra, the $\mathrm{I}_{\mathrm{D}} / \mathrm{I}_{\mathrm{G}}$ of CNFs grown on the RFSAC's surface was 0.98. A low intensity ratio value of $\mathrm{I}_{\mathrm{D}} / \mathrm{I}_{\mathrm{G}}$ indicated a dominant ordered structure or indicated a low level of structural defects in CNFs. On the other hand, if the value of the $\mathrm{I}_{\mathrm{D}} / \mathrm{I}_{\mathrm{G}}$ ratio was high, more structural defects were introduced to the carbon material.

ImageJ was used to obtain the data of CNFs' size. Then, to obtain the CNFs' diameter size distribution, the data were plotted in a histogram diagram analyzed using Origin 8. Figure 8 shows a histogram and Gaussian curve diagram of the CNFs' size distribution, where the resulting curve was asymmetrical. It indicated that the diameter size distribution of CNFs grown on the RFS-activated carbon surface was not uniform or non-homogeneous. The diameter range was $38 \mathrm{~nm}$ and $554 \mathrm{~nm}$. The most commonly formed diameter of CNFs was between 100 and $150 \mathrm{~nm}$, and the average diameter size distribution was around $172 \mathrm{~nm}$ with \pm 8.39 for standard deviation. 


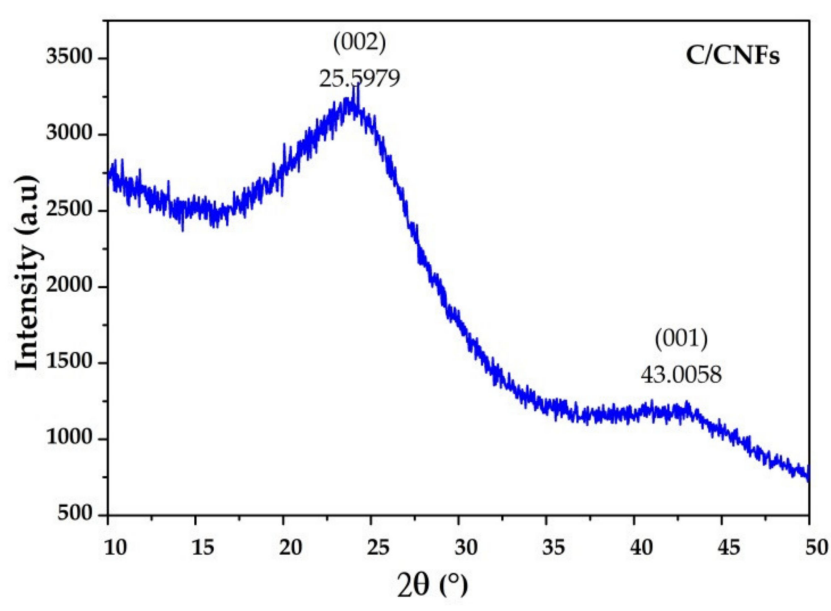

(a)

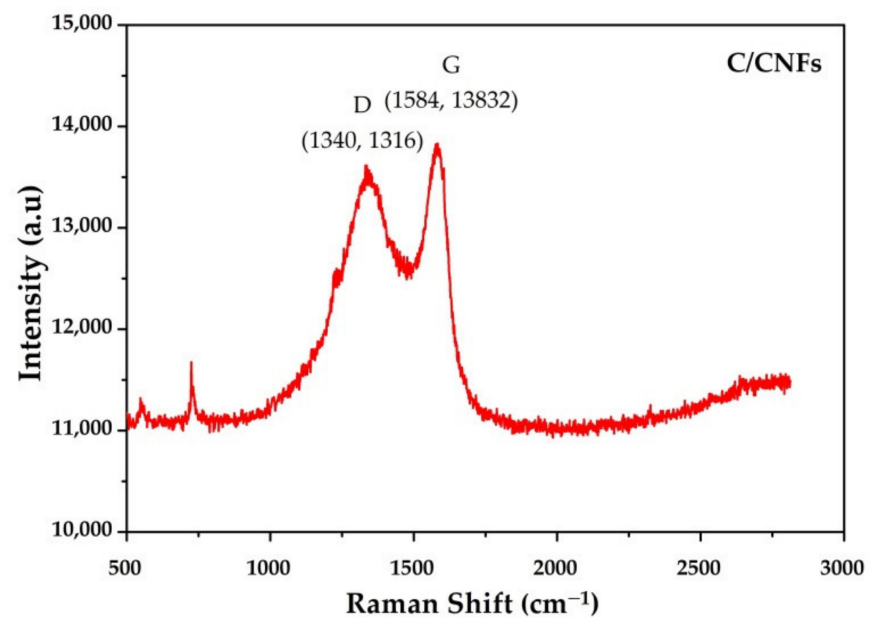

(b)

Figure 7. (a) The XRD pattern of CNFs and (b) Raman Spectra of CNFs.

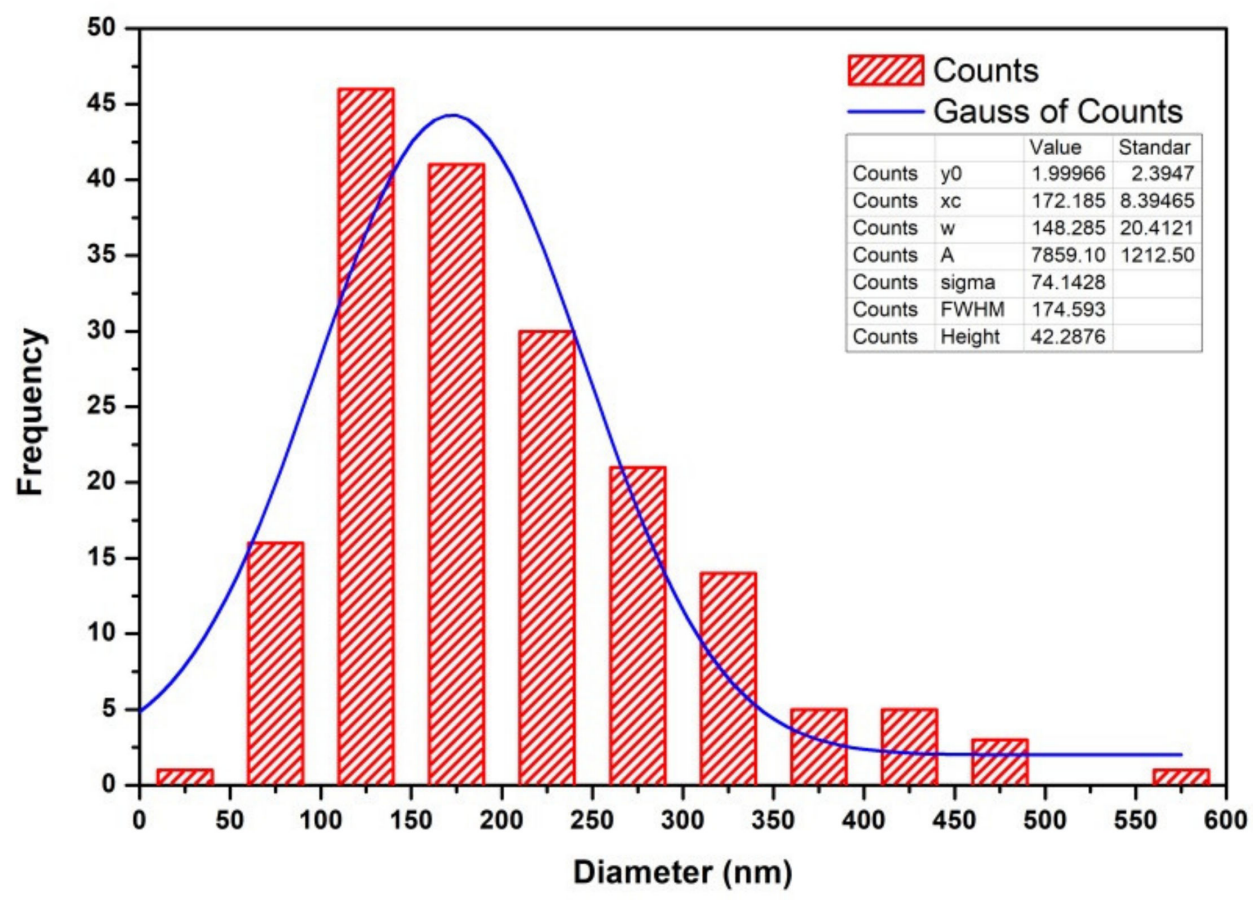

Figure 8. The histogram curve of CNFs diameter distribution.

3.5. Performance of Current CNFs Grown on RFSFAC Surface in Comparison to Other CNFs Produced from Biomass-Activated Carbon

Carbon nanofibers built from biomass have a wide range of qualities and features. Table 2 gives information about the summarization of biomass CNFs' expected results from this study and some of the findings from previous studies. 
Table 2. The performance of carbon nanofiber prepared from various biomass raw materials.

\begin{tabular}{|c|c|c|c|c|c|c|}
\hline Biomass & Synthesis Method & Catalyst & $\operatorname{BET}\left(\mathrm{m}^{2} / \mathrm{g}\right)$ & $\begin{array}{c}\text { CNF Diameter } \\
(\mathrm{nm})\end{array}$ & $\begin{array}{c}\text { Intensity Ratio } \\
\left(\mathrm{I}_{\mathrm{D}} / \mathrm{I}_{\mathrm{G}}\right)\end{array}$ & Ref. \\
\hline $\begin{array}{c}\text { Bamboo } \\
\text { (cellulose fibers) }\end{array}$ & Pyrolysis & - & na & $10-30$ & 0.84 & [16] \\
\hline Sawdust & Pyrolysis & $\mathrm{Fe}$ & $360-421$ & na & $0.9-1.4$ & [52] \\
\hline Natural fungus & $\begin{array}{c}\text { Hydrothermal } \\
\text { technique at } 150^{\circ} \mathrm{C}\end{array}$ & - & 895-1280 & 620 & $1.4-1.55$ & [19] \\
\hline Cellulose & Ultrasonication & & 865 & 200 & 1.21 & [53] \\
\hline $\begin{array}{l}\text { Poplar lignin } \\
\text { powders }\end{array}$ & Electrospinning & & $221-837$ & $80-370$ & $0.73-0.87$ & {$[54]$} \\
\hline RFSAC & $\begin{array}{l}\text { Hydrothermal low } \\
\text { temperature at } 90^{\circ} \mathrm{C}\end{array}$ & - & 63 & $\begin{array}{c}38-554 \\
\text { (172 average) }\end{array}$ & 0.98 & This work \\
\hline
\end{tabular}

Note: na, not available.

\section{Discussion}

Generally, the characteristics of CNFs are determined by the growth conditions. D. Vincent et al. [4] states that there are four steps in the CNF growth mechanism, including the formation of catalyst nanoparticles, carbon adsorption at the catalyst site, carbon through a large portion, and/or diffusion of the catalyst surface, and nucleation. As a result, CNFs involve three main components: gases, an underlayer, and a catalyst. It is well known that the transition metals $\mathrm{Fe}, \mathrm{Ni}$, and Co have been used as a catalyst for CNF synthesis and significantly impact the morphology and performance of CNFs [55]. It is also known that biomass materials as activated carbon precursors can act as catalysts in the synthesis of carbon nanomaterials since some mineral elements are widespread in biomass matrices as essential trace elements for plant growth. Chen et al. [45] discovered CNF clumps on the surface of ACs created from Fe-containing shells of palm kernel, coconut, and wheat straw with the contents of iron in the activated carbon corresponding to $2.91 \%$, $0.17 \%$, and $1.79 \%$, respectively. Their analysis results concluded that Fe particles derived from AC precursors could perform a catalytic role in the formation of CNFs. In addition, to element $\mathrm{Fe}$, due to the significant mineral components of biomass, the functions of other elements during $\mathrm{CNF} / \mathrm{CNT}$ production have attracted the interest of many researchers. For example, K. Shi et al. [56] reported that mineral matter in gumwood containing Si and $\mathrm{Ca}$ acts as a catalyst for the formation of CNTs during a microwave-induced pyrolysis process. The pyrolysis temperature was set to $500{ }^{\circ} \mathrm{C}$ and kept at that temperature for $30 \mathrm{~min}$. The authors deduced that $\mathrm{Si}$ and $\mathrm{Ca}$ decompose volatiles produced by microwaveinduced pyrolysis of gumwood, resulting in the formation of CNTs, where Si and Ca content elements were $0.02 \mathrm{wt} \%$ and $0.06 \mathrm{wt} \%$, respectively. This mechanism of growth of CNFs/CNTs is known as the vapor-solid phase growth model [57]. It has also been reported by Zhang et al. [23] that $0.37 \% \mathrm{~K}$ in pine nut shells is also thought to partially play a catalytic role during the formation and growth of hollow CNFs because It can vaporize as a volatile content and, thus, has a high migration ability at high temperatures.

As discussed above, it shows that the element contents of biomass are generally to be a catalytic component during the preparation of CNFs/CNTs. As shown in Table 1, the CNFs on the surface of the RFSAC consisted of a high element of $\mathrm{C}, \mathrm{O}$, and $\mathrm{P}$, but less than $1 \%$ of $\mathrm{Si}$ and $\mathrm{K}$. This demonstrated that no metal elements were found in CNFs based on RFSAC, implying that no metal elements played a catalytic role in the CNF growth In this study, it can be assumed that even in the absence of a catalyst, the formation of CNFs on the surface of the RFSAC was due to the chemical composition contained in the RFS itself. According to the references, carbon can be dissolved in silicates to generate CNFs/CNTs [56,58]. During the pyrolysis process, elements in the RFS charcoal melted initially and formed droplets on the surface of the charcoal. The melt not only contained elements such as $\mathrm{O}, \mathrm{P}$, and $\mathrm{K}$, but there might also have been silicate in it. As a result, 
it is logical to believe that $\mathrm{Si}$ and $\mathrm{K}$ may play an essential role in $\mathrm{CNF}$ formation during the process.

Another factor that could contribute to the production of CNFs in this study was the chemical composition of RFS. The RFS is a lignocellulosic substance that contains 48.64 percent cellulose [59] and between 35 and 54 percent lignin [6]. The RFS can be easily altered into nano-sized fiber due to the cellulose-linked and hydrogen bond [3]. Additionally, according to Pandia et al. [6], lignin is the most effective natural polymer for creating carbon nanofibers, particularly when phosphoric acid $\left(\mathrm{H}_{3} \mathrm{PO}_{4}\right)$ is added to the lignin solution which results in more curled fibers. This result can be explained by the fact that, aside from the fact that the elemental composition of biomass $(\mathrm{O}, \mathrm{P}, \mathrm{K}$, and $\mathrm{Si})$ is generally considered to be a catalytic component during the preparation of CNFs/CNTs, but also by the fact that the RFS is a natural polymer that can be easily transported into CNFs. Thus, the use of rubber fruit shells as a raw material for CNF production is extremely promising, as it is abundant, renewable, and environmentally beneficial. Additionally, by employing an uncomplicated and straightforward approach that does not require the use of catalysts, does not require vacuum or gas, and is carried out at moderate temperatures, the manufacturing is reasonably safe/harmless and inexpensive.

\section{Conclusions}

CNFs were formed on the surface of the RFSAC (prepared with $\mathrm{H}_{3} \mathrm{PO}_{4}$ activation solution), continuing with the hydrothermal process at a low temperature of $90{ }^{\circ} \mathrm{C}$, where vacuum and gas were not required and without the use of additional catalysts. A SEM and TEM analysis showed many great CNFs with varying diameters on the surface of the RFSAC, where the average diameter size distribution was around $172 \mathrm{~nm}$. The results of the Raman spectroscopy analysis revealed an intensity maxima at around 1340 and $1582 \mathrm{~cm}^{-1}$ as D and G bands were equivalent to those of graphite for CNF characteristics. Similar results were obtained by the $\mathrm{XRD}$ analysis, where an amorphous graphitic carbon structure was formed. TGA and BET results revealed that CNFs have a high thermal stability and surface area $63 \mathrm{~m}^{2} \mathrm{~g}^{-1}$ with an adsorption average pore size of $2.11 \mathrm{~nm}$. Hence, based on the results demonstrated in this study, the RFS is considered an alternative renewable biomass carbon source for CNF preparation, with converting biomass into amorphous carbon through chemical activation and the hydrothermal process.

Author Contributions: Conceptualization, S.S. and S.-C.W.; methodology, S.S.; software, S.S.; validation, S.S. and S.-C.W.; formal analysis, S.S.; investigation, S.S.; resources, S.S.; data curation, S.S. and S.-C.W.; writing-original draft preparation, S.S.; visualization, S.S.; supervision, S.-C.W.; project administration, S.-C.W.; funding acquisition, S.-C.W. All authors have read and agreed to the published version of the manuscript.

Funding: This project and APC was financially supported by the Ministry of Science and Technology of the ROC TAIWAN under contract MOST 109-2221-E-218-013.

Institutional Review Board Statement: Not applicable.

Informed Consent Statement: Not applicable.

Data Availability Statement: Not applicable.

Acknowledgments: The authors are grateful to friends and laboratory technicians at the Southern Taiwan University of Science and Technology's Nano-Functional Ceramics laboratory for assisting in the sample testing process.

Conflicts of Interest: There is no conflict of interest for this research. The funders had no role in the design of the study; in the collection, analyses, or interpretation of data; in the writing of the manuscript, or in the decision to publish the results. 


\section{References}

1. Liu, X.; An, Y.; Feng, J.; Zhu, X.; Li, F. Preparation and Properties of Carbon Nanofiber Modified Emulsified Asphalt Based on Ultrasonication and Surfactant and the Impact of SBR and $\mathrm{NH}_{4} \mathrm{Cl}$. Front. Mater. 2020, 7, 1-9. [CrossRef]

2. Wang, Z.; Wu, S.; Wang, J.; Yu, A.; Wei, G. Carbon nanofiber-based functional nanomaterials for sensor applications. Nanomaterials 2019, 9, 1045. [CrossRef] [PubMed]

3. Azwar, E.; Mahari, W.A.W.; Chuah, J.H.; Vo, D.-V.N.; Ma, N.L.; Lam, W.-H.; Lam, S.S. Transformation of biomass into carbon nanofiber for supercapacitor application-A review. Int. J. Hydrogen Energy 2018, 43, 20811-20821. [CrossRef]

4. Desmaris, V.; Saleem, M.A.; Shafiee, S. Examining carbon nanofibers: Properties, growth, and applications. IEEE Nanotechnol. Mag. 2015, 9, 33-38. [CrossRef]

5. Kumar, M.; Hietala, M.; Oksman, K. Lignin-based electrospun carbon nanofibers. Front. Mater. 2019, 6, 1-6. [CrossRef]

6. Pandia, S.; Sinaga, M.S.; Masyithah, Z.; Husin, A.; Nurfadilla, S.; Fitriani; Sipahutar, B.K.S. Rubber Fruit Shell (Hevea brasiliensis) as bio sorbent to remove FFA (Free Fatty Acid) content in CPO (Crude Palm Oil). IOP Conf. Ser. Mater. Sci. Eng. 2018, $309,012085$. [CrossRef]

7. Sengupta, D.; Chen, S.H.; Michael, A.; Kwok, C.Y.; Lim, S.; Pei, Y.; Kottapalli, A.G.P. Single and bundled carbon nanofibers as ultralightweight and flexible piezoresistive sensors. Npj Flex. Electron. 2020, 4, 1-11. [CrossRef]

8. Feng, L.; Xie, N.; Zhong, J. Carbon nanofibers and their composites: A review of synthesizing, properties and applications. Materials 2014, 7, 3919-3945. [CrossRef]

9. Banitaba, S.N.; Ehrmann, A. Application of electrospun nanofibers for fabrication of versatile and highly efficient electrochemical devices: A review. Polymers 2021, 13, 1741. [CrossRef] [PubMed]

10. Zhou, X.; Liu, B.; Chen, Y.; Guo, L.; Wei, G. Carbon nanofiber-based three-dimensional nanomaterials for energy and environmental applications. Mater. Adv. 2020, 1, 2163-2181. [CrossRef]

11. Kretzschmar, A.; Selmert, V.; Weinrich, H.; Kungl, H.; Tempel, H.; Eichel, R. Tailored Gas Adsorption Properties of Electrospun Carbon Nanofibers for Gas Separation and Storage. ChemSusChem 2020, 13, 3180-3191. [CrossRef]

12. Abdul Khalil, H.P.S.; Adnan, A.S.; Yahya, E.B.; Olaiya, N.G.; Safrida, S.; Hossain, M.S.; Balakrishnan, V.; Gopakumar, D.A.; Abdullah, C.K.; Oyekanmi, A.A.; et al. A review on plant cellulose nanofibre-based aerogels for biomedical applications. Polymers 2020, 12, 1759. [CrossRef] [PubMed]

13. Ashfaq, M.; Verma, N.; Khan, S. Copper/zinc bimetal nanoparticles-dispersed carbon nanofibers: A novel potential antibiotic material. Mater. Sci. Eng. C 2016, 59, 938-947. [CrossRef] [PubMed]

14. Gao, X.; Lan, J.; Jia, X.; Cai, Q.; Yang, X. Improving interfacial adhesion with epoxy matrix using hybridized carbon nanofibers containing calcium phosphate nanoparticles for bone repairing. Mater. Sci. Eng. C 2016, 61, 174-179. [CrossRef] [PubMed]

15. Tao, L.; Huang, Y.; Zheng, Y.; Yang, X.; Liu, C.; Di, M.; Larpkiattaworn, S.; Nimlos, M.R.; Zheng, Z. Porous carbon nanofiber derived from a waste biomass as anode material in lithium-ion batteries. J. Taiwan Inst. Chem. Eng. 2019, 95, 217-226. [CrossRef]

16. Yang, C.; Chen, C.; Pan, Y.; Li, S.; Wang, F.; Li, J.; Li, N.; Li, X.; Zhang, Y.; Li, D. Flexible highly specific capacitance aerogel electrodes based on cellulose nanofibers, carbon nanotubes and polyaniline. Electrochim. Acta 2015, 182, 264-271. [CrossRef]

17. Henrique, M.A.; Neto, W.P.F.; Silvério, H.A.; Martins, D.F.; Gurgel, L.V.A.; da Silva Barud, H.; de Morais, L.C.; Pasquini, D. Kinetic study of the thermal decomposition of cellulose nanocrystals with different polymorphs, cellulose I and II, extracted from different sources and using different types of acids. Ind. Crops Prod. 2015, 76, 128-140. [CrossRef]

18. Liu, H.-J.; Wang, X.-M.; Cui, W.-J.; Dou, Y.-Q.; Zhao, D.-Y.; Xia, Y.-Y. Highly ordered mesoporous carbon nanofiber arrays from a crab shell biological template and its application in supercapacitors and fuel cells. J. Mater. Chem. 2010, 20, 4223-4230. [CrossRef]

19. Deng, L.; Zhong, W.; Wang, J.; Zhang, P.; Fang, H.; Yao, L.; Liu, X.; Ren, X.; Li, Y. The enhancement of electrochemical capacitance of biomass-carbon by pyrolysis of extracted nanofibers. Electrochim. Acta 2017, 228, 398-406. [CrossRef]

20. Mugadza, K.; Stark, A.; Ndungu, P.G.; Nyamori, V.O. Synthesis of Carbon Nanomaterials from Biomass Utilizing Ionic Liquids for Potential Application in Solar Energy Conversion and Storage. Materials 2020, 13, 3945. [CrossRef]

21. Lee, B.-S.; Yu, W.-R. Electrospun carbon nanofibers as a functional composite platform: A review of highly tunable microstructures and morphologies for versatile applications. Funct. Compos. Struct. 2020, 2, 012001. [CrossRef]

22. Inagaki, M.; Yang, Y.; Kang, F. Carbon nanofibers prepared via electrospinning. Adv. Mater. 2012, 24, 2547-2566. [CrossRef]

23. Zhang, J.; Tahmasebi, A.; Omoriyekomwan, J.E.; Yu, J. Direct synthesis of hollow carbon nanofibers on bio-char during microwave pyrolysis of pine nut shell. J. Anal. Appl. Pyrolysis 2018, 130, 142-148. [CrossRef]

24. Pizzi, A.; Duca, D.; Rossini, G.; Fabrizi, S.; Toscano, G. Biofuel, Bioenergy and Feed Valorization of By-Products and Residues from Hevea brasiliensis Cultivation to Enhance Sustainability. Resources 2020, 9, 114. [CrossRef]

25. Oluodo, L.A.; Huda, N.; Komilus, C.F. Potential utilization of rubber seed meal as feed and food potential utilization of rubber seed meal as feed and food. Int. J. Eng. Technol. 2018, 4, 66-71.

26. Sun, K.; Jiang, J.C. Preparation and characterization of activated carbon from rubber-seed shell by physical activation with steam. Biomass Bioenergy 2010, 34, 539-544. [CrossRef]

27. Yan, K.Z.; Zaini, M.A.A.; Arsad, A.; Nasri, N.S. Rubber seed shell based activated carbon by physical activation for phenol removal. Chem. Eng. Trans. 2019, 72, 151-156.

28. Borhan, A.; Yusup, S.; Mun, Y.S. Surface modification of rubber seed shell activated carbon with malic acid for high $\mathrm{CO}_{2}$ adsorption. In Proceedings of the IOP Conference Series: Earth and Environmental Science, West Java, Indonesia, 19-20 August 2019. 
29. Borhan, A.; Yusuf, S. Activation of rubber-seed shell waste by malic acid as potential $\mathrm{CO}_{2}$ removal: Isotherm and kinetics studies. Materials 2020, 13, 4970. [CrossRef] [PubMed]

30. Ekebafe, L.O.; Igbonazobi, L.C.; Anakhu, E.A. Advances in natural rubber seed shell utilization in polymer technology. J. Adv. Sci. Eng. 2020, 3, 106-112. [CrossRef]

31. Naswir, M.; Yasdi; Rahima, S.; Wibowo, Y.G. Rubber fruit shell: Agricultural waste material as a potential sustainable production for wastewater treatment. IOP Conf. Ser. Mater. Sci. Eng. 2020, 801, 012080. [CrossRef]

32. Suhdi; Wang, S.-C. Fine Activated Carbon from Rubber Fruit Shell Prepared by Using $\mathrm{ZnCl}_{2}$ and $\mathrm{KOH}$ Activation. Appl. Sci. 2021, 11, 3994. [CrossRef]

33. Food and Agriculture Organization (FAO). Natural Rubber: Top 10 Producers. 2019. Available online: http://www.fao.org/ faostat/en/\#data/QC/visualize (accessed on 10 January 2021).

34. Indonesia, Direktorat Jenderal Perkebunan Kementerian Pertanian RI. Pembangunan Perkebunan. 2020. Available online: http:/ / ditjenbun.pertanian.go.id/info-publik/laporan-tahunan/ (accessed on 1 July 2021).

35. Julian, R.T. Pemanfaatan Limbah Cangkang Biji Karet Menjadi Briket Sebagai Bahan Bakar Alternatif dengan Bahan Perekat Amilum; Politeknik Negeri Sriwijaya: Palembang, Indonesia, 2017.

36. Ucar, N.; Cavdar, Z.; Karatepe, N.; Altay, P.; Kizildag, N. $\mathrm{SO}_{2}$ Adsorption capability of activated carbon nanofibers produced by different activation process parameters. Text. Appar. 2016, 26, 407-413.

37. Gopiraman, M.; Kim, I.S. Preparation, Characterization, and Applications of Electrospun Carbon Nanofibers and Its Composites. In Electrospinning Electrospraying Techniques and Applications; IntechOpen: London, UK, 2019.

38. Kojima, Y.; Takayasu, M.; Toma, M.; Koda, S. Degradation of cellulose in $\mathrm{NaOH}$ and $\mathrm{NaOH} /$ urea aqueous solutions by ultrasonic irradiation. Ultrason. Sonochem. 2019, 51, 419-423. [CrossRef]

39. Gan, Y.X.; Jayatissa, A.H.; Yu, Z.; Chen, X.; Li, M. Hydrothermal Synthesis of Nanomaterials. J. Nanomater. 2020, 2020. [CrossRef]

40. Wen, Y.; Jiang, M.; Kitchens, C.L.; Chumanov, G. Synthesis of carbon nanofibers via hydrothermal conversion of cellulose nanocrystals. Cellulose 2017, 24, 4599-4604. [CrossRef]

41. Barin, G.B.; De Fátima Gimenez, I.; Da Costa, L.P.; Filho, A.G.S.; Barreto, L.S. Hollow carbon nanostructures obtained from hydrothermal carbonization of lignocellulosic biomass. J. Mater. Sci. 2014, 49, 665-672. [CrossRef]

42. Manafi, S.; Rahaei, M.B.; Elli, Y.; Joughehdoust, S. High-yield synthesis of multi-walled carbon nanotube by hydrothermal method. Can. J. Chem. Eng. 2010, 88, 283-286. [CrossRef]

43. Funke, A.; Ziegler, F. Hydrothermal carbonization of biomass: A summary and discussion of chemical mechanisms for process engineering. Biofuels Bioprod. Biorefining 2010, 4, 160-177. [CrossRef]

44. Rameshwarichanu, M.; Gurumayum, S.; Shijagurumayum, C.; Student, B.E. A review on carbon nanotube. Int. J. Eng. Technol. Manag. Appl. Sci. 2017, 5, 340-348.

45. Chen, X.W.; Timpe, O.; Hamid, S.B.A.; Schlögl, R.; Su, D.S. Direct synthesis of carbon nanofibers on modified biomass-derived activated carbon. Carbon 2009, 47, 340-343. [CrossRef]

46. Yakout, S.M.; El-Deen, G.S. Characterization of activated carbon prepared by phosphoric acid activation of olive stones. Arab. J. Chem. 2016, 9, S1155-S1162. [CrossRef]

47. Arami-Niya, A.; Daud, W.M.A.W.; Mjalli, F.S. Comparative study of the textural characteristics of oil palm shell activated carbon produced by chemical and physical activation for methane adsorption. Chem. Eng. Res. Des. 2011, 89, 657-664. [CrossRef]

48. Hsu, L.-Y.; Teng, H. Influence of different chemical reagents on the preparation of activated carbons from bituminous coal. Fuel Process. Technol. 2000, 64, 155-166. [CrossRef]

49. Su, D.S.; Chen, X.; Weinberg, G.; Klein-Hofmann, A.; Timpe, O.; Hamid, S.B.A.; Schlögl, R. Hierarchically structured carbon: Synthesis of carbon nanofibers nested inside or immobilized onto modified activated carbon. Angew. Chem. Int. Ed. 2005, 44, 5488-5492. [CrossRef]

50. Shenggao, W.; Wen, H.; Mingchen, Z.; Yuan, G.; Quanrong, D.; Yangwu, M.; Qinfang, X.; Geming, W. Synergistic effects of microstructures and active nitrogen content on the oxygen reduction reaction performance of nitrogen-doped carbon nanofibers via $\mathrm{KOH}$ activation heat treatment. J. Mater. Sci. 2020, 55, 10725-10739. [CrossRef]

51. Zhao, X.; Zou, X.; Yan, X.; Brown, C.L.; Chen, Z.-G.; Zhu, G.; Yao, X. Defect-driven oxygen reduction reaction (ORR) of carbon without any element doping. Inorg. Chem. Front. 2016, 3, 417-421. [CrossRef]

52. Liu, W.J.; Tian, K.; He, Y.-R.; Jiang, H.; Yu, H.-Q. High-yield harvest of nanofibers/mesoporous carbon composite by pyrolysis of waste biomass and its application for high durability electrochemical energy storage. Environ. Sci. Technol. 2014, 48, 13951-13959. [CrossRef]

53. Deng, L.; Young, R.J.; Kinloch, I.A.; Abdelkader, A.M.; Holmes, S.M.; De Haro-Del Rio, D.A.; Eichhorn, S.J. Supercapacitance from Cellulose and Carbon Nanotube Nanocomposite Fibers. ACS Appl. Mater. Interfaces 2013, 5, 9983-9990. [CrossRef]

54. Cao, Q.; Zhu, M.; Chen, J.; Song, Y.; Li, Y.; Zhou, J. Novel Lignin-Cellulose-Based Carbon Nanofibers as High-Performance Supercapacitors. ACS Appl. Mater. Interfaces 2020, 12, 1210-1221. [CrossRef]

55. Miniach, E.; Śliwak, A.; Moyseowicz, A.; Gryglewicz, G. Growth of carbon nanofibers from methane on a hydroxyapatitesupported nickel catalyst. J. Mater. Sci. 2016, 51, 5367-5376. [CrossRef]

56. Shi, K.; Yan, J.; Lester, E.; Wu, T. Catalyst-free synthesis of multiwalled carbon nanotubes via microwave-induced processing of biomass. Ind. Eng. Chem. Res. 2014, 53, 15012-15019. [CrossRef] 
57. Wang, Z.; Shen, D.; Wu, C.; Gu, S. State-of-the-art on the production and application of carbon nanomaterials from biomass. Green Chem. 2018, 20, 5031-5057. [CrossRef]

58. Zhu, J.; Jia, J.; Kwong, F.L.; Ng, D.H.L.; Tjong, S.C. Synthesis of multiwalled carbon nanotubes from bamboo charcoal and the roles of minerals on their growth. Biomass Bioenergy 2012, 36, 12-19. [CrossRef]

59. Meilianti, M. Karakteristik Karbon Aktif Dari Cangkang Buah Karet Menggunakan Aktivator $\mathrm{H}_{3} \mathrm{PO}_{4}$. J. Distilasi 2018, 2, 1-9. [CrossRef] 